\title{
THE IMPORTANCE OF ADMINISTERING JUSTICE BY THE COURT OF CASSATION FOR DEVELOPING THE LEGAL SYSTEM OF UKRAINE
}

\section{Bysaga Yu. M.}

\section{INTRODUCTION}

Human rights in today's society play a great role and their importance to any law-based state is scarcely estimable. Individuals and civil society are increasingly aware of the value and practical importance of protecting basic human rights. Any law-based state understands the need for the fundamental development of the idea of the rule of law as the basis not only for its development, but also for the optimal functioning of state power and personality that are even more important.

One of the main elements of the principle of the rule of law and the main means of its functioning is legal certainty, which is increasingly characterized in doctrine and domestic law as an idea of general legal, universal nature, in one form or another, which manifests itself in every branch of domestic procedural law.

One of the determining mechanisms that underscores the public's trust for the country's legal institutions is the ability to have access to justice and certainty of their position.

However, in assessing the level of public trust for domestic justice, in addition to the accessibility of the latter, the role of the highest judicial authority in the country which it executes and its legal conclusions for further improvement of the legal system and the development of domestic law are of great importance. In many countries this role is played by the Supreme Court, since being the supreme judicial authority of the state, and given that its functions are limited to matters of law, the latter's legal conclusions on a certain legal norm concerning a particular case should have legal force and be applied by lower courts when invoking the same norm. Thus, we can talk about the prospects for further development of precedent for interpretating for countries where judicial precedent itself is not a source of law.

\section{Right of access to the court of cassation}

An indicator of the level of development and interaction between the state and civil society is the efficiency of functioning the judicial system in the country, which can guarantee the real protection of the rights, freedoms and interests of the individual and the citizen. 
However, obtaining proper judicial protection and the final decision does not always guarantee the restoration of the violated rights, freedoms and interests of the individual and the citizen. This is due, in particular, to the miscarriage of justice committed by the court, which, according to L. A. Terekhova, is the result of a wrongly resolved case in which the protection of the subject's rights was never provided ${ }^{1}$. The existence of a judicial error in itself guarantees the right to appeal the final decision (the case of "Ryabykh versus Russia"²).

Thus, judicial protection, including several constituent parts (components), where obtaining a decision of the court of first instance is only one of the structural elements of the system ${ }^{3}$ as a guarantee of the legality of the decisions made by the courts of first instance and the appellate court, provides for the right to lodge a cassation appeal ${ }^{4}$.

It follows from the established case law practice of the European Court of Human Rights (hereinafter referred to as the ECHR) that the first paragraph of Article 6 of the Convention for the Protection of Human Rights and Fundamental Freedoms, $19505^{5}$ (hereinafter referred to as the Convention) does not guarantee the right to appeal against the judgment. Nevertheless, the state which creates such a system must provide individuals with the basic guarantees prescribed in Article 6 of the Convention ("Tolstoy-Miloslavsky v. The United Kingdom" ${ }^{\text {}}$ ), in particular, the effective right of access to a higher court ("Levage Prestation Services v. France") Convention is fully applicable to cassation proceedings ("Airey v. Ireland”8).

The importance of the cassation appeal against the court decision is explained by the fact that, as D. I. Kovtkov, in the latter, more than in any other way of appealing, there are combined the public (political) interest of the state, which is manifested in its interest in ensuring the uniformity of law

${ }^{1}$ Терехова Л.А. Система пересмотра судебных актов в механизме судебной защиты: монография. М.: Волтерс Клувер, 2007. С. 33.

${ }^{2}$ ECHR in the case «Ryabykh v. Russia» on July 24, 2003 (Application № 52854/99). URL: http://hudoc.echr.coe.int/eng?i=001-61261 (дата звернення: 26.09.2019).

${ }^{3}$ Терехова Л.А. Система пересмотра судебных актов в механизме судебной защиты: монография. М.: Волтерс Клувер, 2007. С. 1.

${ }^{4}$ Скворцов О.Ю. Институт кассации в российском арбитражном процессуальном праве (проблемы судоустройства и судопроизводства): автореф. дис. на соиск нуч. степени канд. юрид. наук: спец. 12.00.04. Санкт-Петербург, 2000. С. 18.

${ }^{5}$ European Convention on Human Rights. 1950. URL: https://www.echr.coe.int/ Documents/Convention_ENG.pdf\%23page=9 (дата звернення: 26.09.2019).

${ }^{6}$ ECHR in the case «Tolstoy Miloslavsky v. the United Kingdom» on July 13, 1995 (Application № 18139/91). URL: http://hudoc.echr.coe.int/eng?i=001-57947 (дата звернення: 26.09.2019).

7 ECHR in the case «Levages Prestations Service v. France» on October 23, 1996 (Application № 21920/93). URL: http://hudoc.echr.coe.int/eng?i=001-58065 (дата звернення: 26.09.2019).

${ }^{8}$ ECHR in the case «Airey v. Ireland» on October 09, 1979 (Application № 6289/73). URL: http://hudoc.echr.coe.int/eng?i=001-57420 (дата звернення: 26.09.2019). 
enforcement throughout the territory of the state, and the private interest of the parties involved in the process who seek to settle the dispute to their advantage $^{9}$. The highest courts themselves should consider reviewing the errors of the court and justice gaps, but the mere possibility of having two points of view on this issue is not the ground for reconsideration, and the derogation from this principle is justified only when it is necessary to identify circumstances of a substantial and insurmountable nature. ("Ryabykh versus Russia" ${ }^{10}$ ). Consequently, the revision of judgments that have entered into force is possible only in case of exceptional and fundamental judicial errors which result from gross violations of human rights and freedoms and an unfair distribution of rights and responsibilities $1^{11}$, especially where such proceedings concern third parties and their legitimate interests ("Case of Bochan v. Ukraine"12). One way or another, the very fact of the potential for reviewing the adopted court acts is important because it stabilizes the judicial proceedings in the courts of first instance and the appellate court ${ }^{13}$.

The Cabinet of Ministers of the Council of Europe, in its Recommendations, states that complaints to a court of third instance must be filed when cases merit the third trial, such as cases that will develop law or that will promote a uniform interpretation of the law, these cases may also be restricted to complaints related to matters of law which are of importance to the society as a whole and the person, lodging a complaint, is to justify why his / her case would contribute to the attainment of such goals ${ }^{14}$. This indicates that, by its nature, the right of access to a court requires regulation by a state which has some discretion in this matter ("Guerin v. France" ${ }^{15}$ ), and such a right may, in turn, vary over time according to the needs and resources of society and individuals ("Bellett v. France" ${ }^{\text {"16 }}$ ). Thus, we tend to

${ }^{9}$ Ковтков Д.И. Кассационное производство в гражданском процессе: дис. на соиск. науч. степени. канд. юрид. наук: спец. 12.00.15. Москва, 2015. С. 45.

${ }^{10}$ ECHR in the case «Ryabykh v. Russia» on July 24, 2003 (Application № 52854/99). URL: http://hudoc.echr.coe.int/eng?i=001-61261 (дата звернення: 26.09.2019).

11 Вишневский Г.А. Действие принципа res judicata как необходимое условие обеспечения справедливости. Современное право. 2013. № 11. С. 78.

12 ECHR in the case «Bochan v. Ukraine» on May 3, 2007 (Application № 7577/02). URL: http://hudoc.echr.coe.int/eng?i=001-80455 (дата звернення: 26.09.2019).

${ }^{13}$ Курило М.П. Касаційне провадження: можливості його уніфікації. Науковий вісник Ужсгородського національного університету. Серія: Право. 2013. Вип. 22. Т. 1. С. 170.

${ }^{14}$ Рекомендация R (95) 5 Комитета министров государствам-членам относительно введения в действие и улучшения функционирования систем и процедур обжалования по гражданским и торговым делам от 7 февраля 1995 года. URL: http://zakon.rada.gov.ua/ laws/show/994_153 (дата звернення: 26.09.2019).

${ }^{15}$ ECHR in the case «Guérin v. France» on July 29, 1998 (Application № 51/1997/835/1041). URL: http://hudoc.echr.coe.int/eng?i=001-58204 (дата звернення: 26.09.2019).

${ }^{16}$ ECHR in the case «Bellet v. France» on December 4, 1995 (Application № 23805/94). URL: http://hudoc.echr.coe.int/eng?i=001-57952 (дата звернення: 26.09.2019). 
think that access to a court of cassation, because of the specifics of the latter which lies in the fact of reviewing judicial decisions that have entered into force, requires special legislative regulation, as it can either correct a judicial error or violate the legal certainty that came when the contested decision became legally effective.

In this respect the state has the right to establish additional criteria for access to the court of cassation ("Egic v. Croatia" ${ }^{17}$ ). Such criteria will be considered as a legitimate and reasonable procedural requirement, taking into account the very nature of the role of the highest judicial authority, which deals only with matters of law, and therefore, in the framework of a particular case it will be only necessary to determine whether such an interference is consistent with the principle of proportionality between the means employed, namely - the limited access to the court of cassation, and the purpose to be achieved - the person's right to appeal against the court's decision (the case of "Jovanovic v. Serbia" ").

According to H. A. Vyshnevskyi, courts reviewing enacted judgments should have sufficient discretion to determine what can or cannot be considered as a fundamental breach, so that, on the basis of an individual approach to each case, the boundaries of fairness and unfairness can be determined in order not to allow unjustified deviation from the "res judicata" principle" ${ }^{19}$. Indeed, in most European countries, the highest judicial authority has the discretion to select cases for reviewing, using procedural filters that establish the criteria for their selection (the complexity of applying legal norms, cost of litigation, public significance, the importance of the case for determining the direction of the court practices, etc. $)^{20}$. D. D. Lupenyk notes that the fact, that a certain scope of discretion is granted to the highest court in the state judicial system when deciding whether or not there are grounds for revoking or changing court decisions in cassation, provided that this concept is interpretated uniformly in the law enforcement process, - does not contradict the principles of access to justice and this corresponds to the role, place and authority of the court as an independent justice body ${ }^{21}$. M. V. Sydorenko is of the opposite opinion. In particular, the authoress admits that recognizing the possibility of the discretionary

${ }^{17}$ ECHR in the case «Egić v. Croatia » on June 4, 2014 (Application № 32806/09). URL: http://hudoc.echr.coe.int/eng?i=001-144363 (дата звернення: 26.09.2019).

${ }^{18}$ ECHR in the case «Jovanović v. Serbia» on October 2, 2012 (Application № 32299/08). URL: http://hudoc.echr.coe.int/eng?i=001-113294 (дата звернення: 26.09.2019).

19 Вишневский Г.А. Действие принципа res judicata как необходимое условие обеспечения справедливости. Современное право. 2013. № 11. С. 81.

${ }^{20}$ Сердюк В.В. Правовий статус Верховного Суду України в системі судової влади: автореф. дис. ... докт. юрид. наук: спец. 12.00.10. Харків, 2009. С. 7.

21 Луспеник Д.Д. Ідеальний процесуальний кодекс: яким він має бути?. України на шляху до Європи: реформа цивільного процесуального законодавства: матеріали міжнар. наук.-практ. конф. (Київ, 7 лип. 2017 р.). Київ: ВД Дакор, 2017. С. 40. 
judgment of judges in selecting a case before the court proceedings (for a particular case) start, by defining the normative content, casts doubt on the value of such justice and emphasizes the issue of the corruption component of the mentioned activity, its subordination to acts of an non-legal nature ${ }^{22}$.

Under any circumstances, a person's access to court should not be limited or reduced by the criteria of courts' interpretation of procedural rules which regulate the filing of documents or complaints, in such a way or to such an extent that might lead to the violation of the very essence of such a right, and the rules, which regulate the conditions of the admissibility of the complaint, must be provided to the person concerned ("Karakutsia v. Ukraine» case" ${ }^{23}$ ). This highlights, in particular, the notion of "the quality of law" which means the accessibility and predictability of national law, which should lay down sufficiently clear provisions in order to provide people with adequate guidance on the circumstances and conditions under which public authorities have the right to take measures that affect the convention rights of these individuals (the case of "C. G. and others v. Bulgaria" ${ }^{24}$ ).

The fact that the procedural law leaves the determination of the conditions for admissibility of a cassation appeal to the discretion of the law enforcer may, certainly, point to the risk of judicial arbitrariness. However, on the other hand, in addition to the discretionary powers of a supreme judicial authority, the latter may, on the contrary, undermine the very essence of the right to a court by adhering strictly to the procedural rules ("Belesh et al. v. The Czech Republic” ${ }^{25}$ ). We consider it necessary to study this issue in more detail.

The principle of access to court is viewed as negative (which consist in creating no obstacles for people who desire to pursue a judicial remedy if their rights and legitimate interests are violated or contested) and positive (which consist in creating special favourable conditions of such an access, minimum requirements whose meeting must be guaranteed by the state when a person appeals to the court) obligations of the state in the sphere of administering justice ${ }^{26}$, or only as positive ${ }^{27}$ requirements. According to the

${ }^{22}$ Сидоренко М.В. Правовая определенность российского уголовно-процессуального права: дис. ... докт. юрид. наук: спец. 12.00.09. Краснодар, 2017. С. 409.

${ }^{23}$ ECHR in the case «Karakutsya v. Ukraine» on February 16, 2017 (Application № 18986/06). URL: http://hudoc.echr.coe.int/eng?i=001-171475 (дата звернення: 26.09.2019).

${ }^{24}$ ECHR in the case «C.G. and Others v. Bulgaria» on April 24, 2008 (Application № 1365/07). URL: http://hudoc.echr.coe.int/eng?i=001-86093 (дата звернення: 26.09.2019).

${ }^{25}$ ECHR in the case «Běleš and others v. the Czech Republic» on November 12, 2002 (Application № 47273/99). URL: http://hudoc.echr.coe.int/eng?i=001-60750 (дата звернення: 26.09.2019).

${ }^{26}$ Фулей T.I. Застосування Конвенції про захист прав людини і основоположних свобод та практики європейського суду з прав людини: Навчально-методичний посібник для тренерів навчального курсу для суддів. Київ: Ваіте, 2017. С. 37.

27 Ткачук О.С. Реалізація судової влади у цивільному судочинстві України: структурнофункціональний аспект: дис. ... докт. юрид. наук: 12.00.03. Харків, 2016. С. 118. 
results of the research conducted by The World Justice Project "Rule of Law Index 2019" international organization, one of the indicators which determines the accessibility of justice, is, particularly, such a criterion of the latter as the possibility of having an access to judicial system without facing groundless procedural obstacles (p. 13) ${ }^{28}$.

N.V. Tkachova defines procedural $\operatorname{law}^{29}$, as the main instrument for implementing the principle of accessibility of justice, which means that imposing too formalized requirements on the right to appeal a court decision can significantly narrow almost each person's access to a higher court. The ECHR in the case of "Zubac v. Croatia» stated that excessive formalism could contradict the requirement to ensure a practical and effective right of access to a court according to the first paragraph, Article 6 of the Convention, which usually happens in case of a particularly narrow interpretation of a procedural norm which hinders the examination of an applicant's claim and, in fact, with the attendant risk of the violation of his or her right to an effective judicial remedy ${ }^{30}$, and, based on the strictness of procedural rule, courts can undermine the very essence of the law («Karakutsia v. Ukraine» case) ${ }^{31}$. Thus, as the Supreme Court itself points out, one must be guided by one of the axioms of civil litigation: «Placuit in omnibus rebus praecipuum esse iustiae aequitatisque quam stricti iuris rationem», which means: «In all legal cases, justice and fairness take precedence over the strict understanding of law"32.

In view of the above, we consider that the imposition of legal restrictions on access to the court of cassation is justified, taking into account the caution against the inadmissibility of its transformation into the next court of third instance, since, otherwise, it may lead to the creation of subsequent instances, and consequently, the protection of rights, freedoms and interests may never occur due to an "endless" litigation. However, in order to achieve the primary goal of justice, it is necessary to increase public trust in lower courts and to destroy the postulate according to which the higher the court, the more effective judicial protection is.

\footnotetext{
${ }^{28}$ The World Justice Project «Rule of Law Index 2019». 2019. 201 c. URL: https://worldjusticeproject.org/sites/default/files/documents/WJP_RuleofLawIndex_2019_Websi te_reduced.pdf (дата звернення: 26.09.2019).

${ }^{29}$ Ткачева Н.В. Принцип доступности правосудия в практике Європейского суда по правам человека. Вестник ЮУрГУ № 38. Серия: Право. 2010. Вып. 24. С.71.

${ }^{30}$ ECHR in the case «Zubac v. Croatia» on April 5, 2018 (Application № 40160/12). URL: http://hudoc.echr.coe.int/eng?i=001-181821 (дата звернення: 26.09.2019).

31 ECHR in the case «Karakutsya v. Ukraine» on February 16, 2017 (Application № 18986/06). URL: http://hudoc.echr.coe.int/eng?i=001-171475 (дата звернення: 26.09.2019).

32 Ухвала Верховного Суду від 4 квітня 2018 року № 310/11534/13-ц. URL: http://reyestr.court.gov.ua/Review/73335565 (дата звернення: 26.09.2019).
} 


\section{The significance of the Supreme Court's legal conclusions for the development of case law in Ukraine}

In assessing the level of public trust in domestic justice, in addition to the accessibility of the latter, of great importance is the fact that it executes the role of the highest judicial authority in the country and its legal conclusions contribute to further improvement of the legal system and the development of national legislation.

Since 2015, the judicial reform ${ }^{33}$, has begun in Ukraine, affecting most legal institutions.

The analysis of the state of Ukrainian justice prior to the beginning of the reform was determined by the low level of trust in the judiciary in general and the judges in particular (paragraph 3 of Strategy of reforming judicial organization, court proceedings, and Related Legal Institutions), in connection with which the judicial corps was updated, in particular, the retraining of judges in order to determine the level of professional competence $^{34}$ and, what is more important for our study, the creation of a new supreme judicial authority - the Supreme Court.

For example, on April 8, 2019, the Council of Europe published "The Conclusions on the procedure for selecting and appointing judges (to the Supreme Court of Ukraine) on compliance of the procedure with the standards of the Council of Europe" ${ }^{35}$, which assessed approvingly the legislative framework for the selection and appointment of judges, which, in turn, is positively characterized by a high level of publicity (p. 31). However, it would be impractical and cost-effective to impose such a procedure on all instances, both temporally and financially. Thus, the Supreme Court should be entitled to such powers that it can become the cornerstone for building a new Ukrainian judicial system based on confidence in domestic justice.

A judicial instance is defined as a procedural judicial category, which determines a set of jurisdictional powers of a particular judicial authority in relation to a particular category of cases, as well as to which particular branch of the judicial system such powers are conferred ${ }^{36}$. Thus, the authority of the Supreme Court as a cassation instance is restricted to to verifying the legality of the court decisions (Article 300 of the Code of

33 Про стратегію реформування судоустрою, судочинства та суміжних правових інститутів на 2015-2020 роки: Указ Президента України від 20 травня 2015 року № 276/2015. Офіиійний вісник Украӥни. 2015. № 41. Ст. 1267.

34 Про відновлення довіри до судової влади в Україні: Закон України від 8 квітня 2014 року № 1188-VII. Відомості Верховної Ради Украӥни. 2014. № 23. Ст. 870.

${ }^{35}$ On the procedure for selection and appointment of judges to the Supreme Court in Ukraine with the focus on its compliance with the standards of the Council of Europe: Opinion. Support to the implementation of the judicial reform in Ukraine. October 2017 - February 2018. 39 p. URL: https://rm.coe.int/coe-opinion-competition-sc/168093d89e (дата звернення: 26.09.2019).

${ }^{36}$ Судова влада: монографія / за заг. ред. проф. І.С. Марочкіна. Х.: Право, 2015. С. 463. 
Commercial Procedure of Ukraine ${ }^{37}$, Article 400 of the Civil Procedural Code of Ukraine ${ }^{38}$, Article 341 of the Code of Administrative Procedure of Ukraine $^{39}$, Article 433 of the Criminal Procedural Code of Ukraine ${ }^{40}$ ).

The European Court of Human Rights (hereafter referred to as ECHR) repeatedly drew attention to the special status of the Supreme Court as the highest judicial authority of the state (for example, the case of "Yovanovic v. Serbia” ${ }^{41}$ ), recognizing different criteria of access to the latter, such as a higher degree of formality to the procedure of access to a court (the case of "Brualla Gomez de la Torre v. Spain" ${ }^{42}$ ), higher court fees (the case of "Egic versus Croati” ${ }^{43}$ ) etc. However, neither the ECHR nor any other democratic country denied the existence of this judicial authority. Does the special status of this judicial authority lie in the fact of limiting access to the latter?

So, in conditions of the European Integration globalization processes have great significance for Ukraine, particularly, for law. For example, A. H. Karas stresses that the main impact of globalization on law is manifested in its universalization, which, additionally, consists in eliminating the contradictions between national legal systems, where law becomes an important instrument of such globalization ${ }^{44}$.

Judicial reform in Ukraine ${ }^{45}$ has given a significant impetus to the development of case law in the country. Thus, according to the amendments to Part 6 of Article 13 of the Law of Ukraine "On Judicature and Status of Judges $^{46}$, the conclusions on the application of the rules of law set forth in the rulings of the Supreme Court are taken into account by other courts when

${ }^{37}$ Господарський процесуальний кодекс України від 6 листопада 1991 року № 1798-XII. Відомості Верховної Ради України. 1992. № 6. Ст. 56.

${ }^{38}$ Цивільний процесуальний кодекс України від 18 березня 2004 року № 1618-IV. Офіційний вісник України. 2004. № 16. Ст. 1088.

${ }^{39}$ Кодекс адміністративного судочинства України від 6 липня 2005 року № 2747-IV. Урядовий кур 'єр. № 153.

${ }^{40}$ Кримінальний процесуальний кодекс України від 13 квітня 2012 року № 4651-VI. Голос України. 2012. № 90-91.

${ }^{41}$ ECHR in the case «Jovanović v. Serbia» on October 2, 2012 (Application № 32299/08). URL: http://hudoc.echr.coe.int/eng?i=001-113294 (дата звернення: 26.09.2019).

${ }^{42}$ ECHR in the case « Brualla Gómez de la Torre v. Spain» on December 19, 1997 (Application № 26737/95). URL: http://hudoc.echr.coe.int/eng?i=001-58127 (дата звернення: 26.09.2019).

${ }^{43}$ ECHR in the case «Egić v. Croatia » on June 4, 2014 (Application № 32806/09). URL: http://hudoc.echr.coe.int/eng?i=001-144363 (дата звернення: 26.09.2019).

${ }^{44}$ Карась А.Г. Глобалізація як чинник трансформації права. Держава і право. 2012. Вип. 57. С. 91.

45 Про стратегію реформування судоустрою, судочинства та суміжних правових інститутів на 2015-2020 роки: Указ Президента України від 20 травня 2015 року № 276/2015. Офіційний вісник України. 2015. № 41. Ст. 1267.

${ }^{46}$ Про внесення змін до Господарського процесуального кодексу України, Цивільного процесуального кодексу України, Кодексу адміністративного судочинства України та інших законодавчих актів: Закон України від 3 жовтня 2017 року № 2147-VIII. Відомості Верховної Ради Украӥни. 2017. № 48. Ст. 436. 
applying such rules of law. However, the idea «court must take into account» means «familiarization and reflection" ${ }^{47}$.

According to scientific theory, a judicial precedent of law is a decision of a court which has a general normative character, that is, when considering cases, the court is guided by the decision that once was adopted by this very court (or another one) in a similar case. In accordance with foreign practices, where precedents are recognized as a source of law, the latter ones are of a general rather than a compulsory nature - courts may draw on the previous court decision in a similar case, but they may produce their own decision, which, in case of its further application by this or that court, may acquire the features of a judicial precedent ${ }^{48}$. The precedent can also repeal the law, not directly, but in the process of its application (by means of interpretation of the law) ${ }^{49}$.

Nevertheless, there is a need to distinguish between a judicial precedent and precedent-interpretation. The latter, in particular, consists in interpreting a rule of law exercised by the highest judicial instance ${ }^{50}$, resulting in a legislative provision which exists in an altered state ${ }^{51}$, and differs from a judicial precedent in the fact that it is always based on law ${ }^{52}$. The precedentinterpretation thus acts not as a law-making process, but as an enforcement, but of a normative (binding) nature ${ }^{53}$.

Indeed, jurisprudence is increasingly recognized as a source of law. However, such recognition does not imply that law-making powers are entrusted to supreme judicial bodies. In this way, the jurisprudence informs the legislative body of the country about the existing problems, about the failure of law to regulate a number of relations that require such regulation. The courts themselves do not deal with such regulation. The jurisprudence serves solely as a factor in lawmaking, on the basis of which new norms of law are formed ${ }^{54}$.

47 Рішення Кіровоградського окружного адміністративного суду від 26 лютого 2018 року № П/811/231/18. URL: http://www.reyestr.court.gov.ua/Review/72406625 (дата звернення: 26.09.2019).

${ }^{48}$ Овсепян Ж.И. Толкование как функция высших судов Российской Федерации. Толкование правовых актов (теоретико-правовой, конституционно-правовой, гражданскоправовой и трудо-правовой аспекты) : материалы Всероссийской научно-практической конференции. Симферополь: ИТ АРИАЛ, 2017. С. 64.

${ }_{49}$ Маркин С.В. Судебный прецедент как источник международного частного права: автореф. дис. ... канд. юрид. наук: 12.00.03. Волгоград, 2005. С. 21.

${ }^{50}$ Гук П.А. Судебное толкование и применение норм законодательства. Известия выстих учебных заведений. Поволжский регион. Общественные науки. 2016. № 2 (38). С. 37.

${ }^{51}$ Васянович О.А. Правовий звичай як форма права у сучасніих правових системах: автореф. дис. ... канд. юр. наук: 12.00.01. Київ, 2010. С. 10.

52 Тонков Е.Н. Английский прецедент и Российский прецедент толкования: соотношение феноменов. Вестник Московского университета МВД России. 2013. № 10. С. 30.

53 Гицу М.А. Судебный прецедент как источник права в свете современных тенденций в России. Государство и право. 2017. № 6. С. 11.

54 Морозова Л.А. Судебные акты и их роль в правообразовании. Провинцииальные научные записки. 2018. № 2 (8). С. 28-29. 
This position has repeatedly been endorsed by the ECHR. Indeed, courts must be the first ones to interpret the domestic law, including procedural norms («Saez Maezo v. Spain» ${ }^{55}$ ). Since the pursuit of law is a task for lawmakers, law enforcement bodies and officials, especially judges who apply legal norms to specific situations before others identify flaws in the law, and sometimes, because of gaps in the latter, they are engaged in creating law ${ }^{56}$. We, in turn, support the idea that each case is different from one another in one way or another. But at the same time, the unequal application of the same legal norms by courts of different instances, as well as the maintenance of controversial judgments, can cause a state of legal uncertainty that can diminish public confidence in the judicial system, whereas such certainty is undoubtedly one of the most important components of a law-based state (the case of "Nejdet Şahin and Perihan Şahin v. Turkey" ${ }^{57}$ ).

In the case of "Atanasovski v. the former Republic of Macedonia" 58 , the ECHR noted that the development of case law does not contravene the proper administration of justice, since the failure to maintain a dynamic and evolutionary approach can lead to obstacles to reforming or improving the judiciary. Even the existence of conflicting judgments, although within the same court, cannot be considered a violation of the right to a fair trial ("Santos Pinto v. Portugal" ${ }^{59}$ ), even if the decisions were made in similar proceedings, since the independence of these courts must be respected (“Gregorio de Andrade v. Portugal” case ${ }^{60}$ ).

An inherent feature of any judicial system is developing jurisprudence (the case of "the Parish of the Greek Catholic Church of Lupen and Others v. Romania”61), and each state is responsible for organizing its judicial system in such a way as to avoid adopting contradictory decisions (the case of "Brezovica v. Croatia"62). And if divergent practice is developed in one of

55 ECHR in the case «Saez Maeso v. Spain» on November 9, 2005 (Application № 77837/01). URL: http://hudoc.echr.coe.int/eng?i=001-67338 (дата звернення: 26.09.2019).

${ }^{56}$ Гураленко Н.А. Судовий прецедент в системі джерел права: філософсько-правовий аспект: дис. .... канд. юр. наук: 12.00.12. Львів, 2009. С. 173.

${ }^{57}$ ECHR in the case «Nejdet Sahin and Perihan Sahin v. Turkey» on October 20, 2011 (Application № 13279/05). URL: http://hudoc.echr.coe.int/eng?i=001-107156 (дата звернення: 26.09.2019).

${ }^{58}$ ECHR in the case «Atanasovski v. the former Yugoslav Republic of Macedonia» on January 14, 2010 (Application № 36815/03). URL: http://hudoc.echr.coe.int/eng?i=001-96673 (дата звернення: 26.09.2019).

59 ECHR in the case «Santos Pinto v. Portugal» on May 20, 2008 (Application № 39005/04). URL: http://hudoc.echr.coe.int/eng?i=001-86401 (дата звернення: 26.09.2019).

${ }^{60}$ ECHR in the case «Gregório de Andrade v. Portugal» on November 14, 2007 (Application № 41537/02). URL: http://hudoc.echr.coe.int/eng?i=001-77967 (дата звернення: 26.09.2019).

${ }^{61}$ ECHR in the case «Lupeni Greek Catholic Parish and Others v. Romania» on November 29, 2016 (Application № 76943/11). URL: http://hudoc.echr.coe.int/eng?i=001-169054 (дата звернення: 26.09.2019).

${ }^{62}$ ECHR in the case «Brezovec v. Croatia» on March 29, 2011 (Application № 13488/07). URL: http://hudoc.echr.coe.int/eng?i=001-104155 (дата звернення: 26.09.2019). 
the highest courts in the country, it itself becomes a source of legal uncertainty, undermining the principle of legal certainty and reducing public confidence in the judicial system (the case of "Çelebi and Others v. Turkey" ${ }^{63}$ ). Thus, the judicial system must create effective mechanisms that should be fully and promptly implemented through the highest judicial authorities which are responsible for ensuring the uniformity of case law, so as to remedy, at any stage, any discrepancies in the decisions of different courts, and thus to maintain public confidence in the judiciary ("Albu and Others v. Romania" ${ }^{64}$ ).

That is why the Supreme Court is intended to resolve the contradictions in applying the same legal norm by the courts ("Beian v. Romania”"65), because this Court is the source of the differences in case law and is responsible for the stability of jurisprudence ("Ferreira Santos Pardal v. Portugal" case ${ }^{66}$ ).

By their legal nature, judicial legal positions are formed with the help of the interpretation of regulations, the application of the analogy of law and rights, the direct appeal of the courts to the principles of law. In this capacity, they are the result of individual judicial regulation and serve as a means of transition to the certainty of legal provisions. Having such an idea of the correct understanding and application of rule of law on the basis of a judicial legal position transforms it into a holistic solution to the contentious legal issue ${ }^{67}$.

\section{CONCLUSIONS}

Hence, we are of the opinion that access to the court of cassation, because of the specifics of the latter which lies in reviewing judicial decisions that have entered into force, requires special legislative regulation, as it can either correct a judicial error or violate the legal certainty that came when the contested decision entered into legal force.

Establishing legal restrictions on access to a court of cassation is justified, taking into consideration the warning of inadmissibility of turning it into a regular court of third instance, since, otherwise, it may lead to the formation of subsequent instances, resulting in a situation when rights, freedoms and interests cannot be protected due to an «endless» litigation. Nevertheless, in order to achieve the primary purpose of justice, it is necessary to increase

${ }^{63}$ ECHR in the case «Çelebi and Others v. Turkey» on February 9, 2016 (Application № 582/05). URL: http://hudoc.echr.coe.int/eng?i=001-160415 (дата звернення: 26.09.2019).

${ }^{64}$ ECHR in the case "Albu and Others v. Romania» on May 10, 2012 (Application № 34796/09). URL: http://hudoc.echr.coe.int/eng?i=001-110805 (дата звернення: 26.09.2019).

${ }^{65}$ ECHR in the case «Beian v. Romania» on December 6, 2007 (Application № 30658/05). URL: http://hudoc.echr.coe.int/eng?i=001-83822 (дата звернення: 26.09.2019).

${ }^{66}$ ECHR in the case «Ferreira Santos Pardal v. Portugal» on July 30, 2015 (Application № 30123/10). URL: http://hudoc.echr.coe.int/eng?i=001-156500 (дата звернення: 26.09.2019).

${ }^{67}$ Шульга И.В. Понятие и виды правовых позиций Верховного суда Российской Федерации: автореф. дис. ... канд. юрид. наук: 12.00.01. М., 2016. С. 14. 
public confidence in lower courts and to erode the postulate, according to which the higher the court, the more effective judicial protection is.

Despite this, neither the ECHR in its practice nor any democratic country has denied the existence of this judicial body.

The precedent-interpretation is defined as the activity of the highest judicial bodies, which, when deciding a particular case, if the need for interpreting a legal norm emerges, are guided by the general principles of law envisaged by the Constitution and international normative legal acts that have supreme legal force. Such general principles of law, which are selected by a court within a certain legal norm, cannot be outdated a priori.

In this regard, the author expresses his support for the point of view that lower courts are not entitled to depart from the legal position of the Supreme Court in cases under similar circumstances.

\section{SUMMARY}

The paper reveals the legal nature of the cassation against court decisions as well as the status of the Supreme Court as the highest judicial authority. Currently, in many countries (including Ukraine), the functions of the latter are limited to issues of law, and the legislation provides criteria which restrict access to court of cassation.

The expediency of such restrictions is justified in the light of the warning of inadmissibility of its transformation into the next court of third instance, as otherwise it may lead to the creation of further judicial bodies, and this may result in the failure to protect rights, freedoms and interests due to an «infinite» legal battle.

The article addresses the challenging issues of determining the place and role of the Supreme Court, namely, its importance for the development of the legal system of the continental law. The author's position on the expediency of giving legal powers to the Supreme Court's conclusions on legal issues, which is the basis of developing the precedent of interpretation in Ukraine, is justified.

\section{REFERENCES}

1. Терехова Л.А. Система пересмотра судебных актов в механизме судебной защиты: монография. М.: Волтерс Клувер, 2007. 320 с.

2. ECHR in the case «Ryabykh v. Russia» on July 24, 2003 (Application № 52854/99). URL: http://hudoc.echr.coe.int/eng?i=001-61261 (дата звернення: 26.09.2019).

3. Скворцов О.Ю. Институт кассации в российском арбитражном процессуальном праве (проблемы судоустройства и судопроизводства): автореф. дис. на соиск нуч. степени канд. юрид. наук: спец. 12.00.04. Санкт-Петербург, 2000. 24 с. 
4. European Convention on Human Rights. 1950. URL: https://www.echr.coe.int/Documents/Convention_ENG.pdf\%23page=9 (дата звернення: 26.09.2019).

5. ECHR in the case "Tolstoy Miloslavsky v. the United Kingdom" on July 13, 1995 (Application № 18139/91). URL: http://hudoc.echr.coe.int/ eng? $\mathrm{i}=001-57947$ (дата звернення: 26.09.2019).

6. ECHR in the case "Levages Prestations Service v. France" on October 23, 1996 (Application № 21920/93). URL: http://hudoc.echr.coe.int/ eng? $\mathrm{i}=001-58065$ (дата звернення: 26.09.2019).

7. ECHR in the case "Airey v. Ireland" on October 09, 1979 (Application № 6289/73). URL: http://hudoc.echr.coe.int/eng?i=001-57420 (дата звернення: 26.09.2019).

8. Ковтков Д.И. Кассационное производство в гражданском процессе: дис. ... канд. юрид. наук: спец. 12.00.15. Москва, 2015. 197 с.

9. Вишневский Г.А. Действие принципа res judicata как необходимое условие обеспечения справедливости. Современное право. 2013. № 11. C. 76-83.

10. ECHR in the case "Bochan v. Ukraine" on May 3, 2007 (Application № 7577/02). URL: http://hudoc.echr.coe.int/eng?i=001-80455 (дата звернення: 26.09.2019).

11. Курило М.П. Касаційне провадження: можливості його уніфікації. Науковий вісник Ужггородського національного університету. Серія: Право. 2013. Вип. 22. Т. 1. С. 167-170.

12. Рекомендация $\mathrm{R}$ (95) 5 Комитета министров государствам-членам относительно введения в действие и улучшения функционирования систем и процедур обжалования по гражданским и торговым делам от 7 февраля 1995 года. URL: http://zakon.rada.gov.ua/laws/show/994_153 (дата звернення: 26.09.2019).

13. ECHR in the case "Guérin v. France» on July 29, 1998 (Application № 51/1997/835/1041). URL: http://hudoc.echr.coe.int/eng?i=001-58204 (дата звернення: 26.09.2019).

14. ECHR in the case «Bellet v. France» on December 4, 1995 (Application № 23805/94). URL: http://hudoc.echr.coe.int/eng?i=001-57952 (дата звернення: 26.09.2019).

15. ECHR in the case "Egić v. Croatia" on June 4, 2014 (Application № 32806/09). URL: http://hudoc.echr.coe.int/eng?i=001-144363 (дата звернення: 26.09.2019).

16. ECHR in the case «Jovanović v. Serbia» on October 2, 2012 (Application № 32299/08). URL: http://hudoc.echr.coe.int/eng?i=001-113294 (дата звернення: 26.09.2019).

17. Сердюк В.В. Правовий статус Верховного Суду України в системі судової влади: автореф. дис. ... докт. юрид. наук: спец. 12.00.10. Харків, 2009. 36 с. 
18. Луспеник Д.Д. Ідеальний процесуальний кодекс: яким він має бути?. України на шляху до Свропи: реформа цивільного процесуального законодавства: матеріали міжнар. наук.-практ. конф. (Київ, 7 лип. 2017 р.). Київ: ВД Дакор, 2017. С. 36-47.

19. Сидоренко М.В. Правовая определенность российского уголовнопроцессуального права: дис. ... докт. юрид. наук: спец. 12.00.09. Краснодар, 2017. 557 c.

20. ECHR in the case "Karakutsya v. Ukraine” on February 16, 2017 (Application № 18986/06). URL: http://hudoc.echr.coe.int/eng?i=001-171475 (дата звернення: 26.09.2019).

21. ECHR in the case «C.G. and Others v. Bulgaria» on April 24, 2008 (Application № 1365/07). URL: http://hudoc.echr.coe.int/eng?i=001-86093 (дата звернення: 26.09.2019).

22. ECHR in the case "Běleš and others v. the Czech Republic" on November 12, 2002 (Application № 47273/99). URL: http://hudoc.echr.coe.int/ eng?i=001-60750 (дата звернення: 26.09.2019).

23. Фулей T.I. Застосування Конвенції про захист прав людини i основоположних свобод та практики європейського суду 3 прав людини: Навчально-методичний посібник для тренерів навчального курсу для суддів. Київ: Ваіте, 2017. 208 с.

24. Ткачук О.С. Реалізація судової влади у цивільному судочинстві України: структурно-функціональний аспект: дис. ... докт. юрид. наук: 12.00.03. Харків, 2016. $547 \mathrm{c.}$

25. The World Justice Project "Rule of Law Index 2019”. 2019. 201 c. URL: https://worldjusticeproject.org/sites/default/files/documents/WJP_ RuleofLawIndex_2019_Website_reduced.pdf (дата звернення: 26.09.2019).

26. Ткачева Н.В. Принцип доступности правосудия в практике Європейского суда по правам человека. Вестник ЮУрГУ № 38. Серия: Право. 2010. Вып. 24. С. 71-73.

27. ECHR in the case "Zubac v. Croatia" on April 5, 2018 (Application № 40160/12). URL: http://hudoc.echr.coe.int/eng?i=001-181821 (дата звернення: 26.09.2019).

28. Ухвала Верховного Суду від 4 квітня 2018 року № 310/11534/13-ц. URL: http://reyestr.court.gov.ua/Review/73335565 (дата звернення: 26.09.2019).

29. Про стратегію реформування судоустрою, судочинства та суміжних правових інститутів на 2015-2020 роки: Указ Президента України від 20 травня 2015 року № 276/2015. Офіиійний вісник Украӥни. 2015. № 41. Ст. 1267.

30.Про відновлення довіри до судової влади в Україні: Закон України від 8 квітня 2014 року № 1188-VII. Відомості Верховної Ради України. 2014. № 23. Ст. 870. 
31. On the procedure for selection and appointment of judges to the Supreme Court in Ukraine with the focus on its compliance with the standards of the Council of Europe: Opinion. Support to the implementation of the judicial reform in Ukraine. October 2017 - February 2018. 39 p. URL: https://rm.coe.int/coe-opinion-competition-sc/168093d89e (дата звернення: 26.09.2019).

32. Судова влада: монографія / за заг. ред. проф. I.С. Марочкіна. Х.: Право, 2015. 792 с.

33. Господарський процесуальний кодекс України від 6 листопада 1991 року № 1798-XII. Відомості Верховної Ради України. 1992. № 6. Ст. 56.

34. Цивільний процесуальний кодекс України від 18 березня 2004 року № 1618-IV. Офіиійний вісник Украӥни. 2004. № 16. Ст. 1088.

35. Кодекс адміністративного судочинства України від 6 липня 2005 року № 2747- IV. Урядовий кур’єр. № 153.

36. Кримінальний процесуальний кодекс України від 13 квітня 2012 року № 4651- VI. Голос України. 2012. № 90-91.

37. ECHR in the case "Brualla Gómez de la Torre v. Spain" on December 19, 1997 (Application № 26737/95). URL: http://hudoc.echr.coe.int/ eng?i=001-58127 (дата звернення: 26.09.2019).

38. Карась А.Г. Глобалізація як чинник трансформації права. Держава і право. 2012. Вип. 57. С. 88-94.

39. Про внесення змін до Господарського процесуального кодексу України, Цивільного процесуального кодексу України, Кодексу адміністративного судочинства України та інших законодавчих актів: Закон України від 3 жовтня 2017 року № 2147-VIII. Відомості Верховної Ради Украӥни. 2017. № 48. Ст. 436.

40. Рішення Кіровоградського окружного адміністративного суду від 26 лютого 2018 року № П/811/231/18. URL: http://www.reyestr.court.gov.ua/ Review/72406625 (дата звернення: 26.09.2019).

41. Овсепян Ж.И. Толкование как функция высших судов Российской Федерации. Толкование правовых актов (теоретико-правовой, конститучионно-правовой, гражданско-правовой и трудо-правовой аспекты) : материалы Всероссийской научно-практической конференции. Симферополь: ИТ АРИАЛ, 2017. С. 62-66.

42. Маркин С.В. Судебный прецедент как источник международного частного права: автореф. дис. ... канд. юрид. наук: 12.00.03. Волгоград, 2005. $34 \mathrm{c}$.

43.Гук П.А. Судебное толкование и применение норм законодательства. Известия ввысших учебных заведений. Поволжский регион. Общественные науки. 2016. № 2 (38). С. 35-43. 
44. Васянович О.А. Правовий звичай як форма права у сучасних правових системах: автореф. дис. ... канд. юрид. наук: 12.00.01. Київ, 2010. $18 \mathrm{c}$.

45. Тонков Е.Н. Английский прецедент и Российский прецедент толкования: соотношение феноменов. Вестник Московского университета МВД России. 2013. № 10. С. 27-32.

46. Гицу М.А. Судебный прецедент как источник права в свете современных тенденций в России. Государство и право. 2017. № 6. C. 5-16.

47. Морозова Л.А. Судебные акты и их роль в правообразовании. Провинииальные научные записки. 2018. № 2 (8). С. 27-33.

48. ECHR in the case «Saez Maeso v. Spain» on November 9, 2005 (Application № 77837/01). URL: http://hudoc.echr.coe.int/eng?i=001-67338 (дата звернення: 26.09.2019).

49. Гураленко Н.А. Судовий прецедент в системі джерел права: філософсько-правовий аспект: дис. ... канд. юр. наук: 12.00.12. Львів, 2009. $223 \mathrm{c}$.

50. ECHR in the case "Nejdet Sahin and Perihan Sahin v. Turkey" on October 20, 2011 (Application № 13279/05). URL: http://hudoc.echr.coe.int/ eng?i=001-107156 (дата звернення: 26.09.2019).

51.ECHR in the case "Atanasovski v. the former Yugoslav Republic of Macedonia” on January 14, 2010 (Application № 36815/03). URL: http://hudoc.echr.coe.int/eng?i=001-96673 (дата звернення: 26.09.2019).

52. ECHR in the case "Santos Pinto v. Portugal" on May 20, 2008 (Application № 39005/04). URL: http://hudoc.echr.coe.int/eng?i=001-86401 (дата звернення: 26.09.2019).

53. ECHR in the case "Gregório de Andrade v. Portugal" on November 14, 2007 (Application № 41537/02). URL: http://hudoc.echr.coe.int/eng?i= 001-77967 (дата звернення: 26.09.2019).

54.ECHR in the case "Lupeni Greek Catholic Parish and Others v. Romania” on November 29, 2016 (Application № 76943/11). URL: http://hudoc.echr.coe.int/eng?i=001-169054 (дата звернення: 26.09.2019).

55. ECHR in the case "Brezovec v. Croatia" on March 29, 2011 (Application № 13488/07). URL: http://hudoc.echr.coe.int/eng?i=001-104155 (дата звернення: 26.09.2019).

56. ECHR in the case "Çelebi and Others v. Turkey" on February 9, 2016 (Application № 582/05). URL: http://hudoc.echr.coe.int/eng?i=001-160415 (дата звернення: 26.09.2019).

57. ECHR in the case "Albu and Others v. Romania" on May 10, 2012 (Application № 34796/09). URL: http://hudoc.echr.coe.int/eng?i=001110805 (дата звернення: 26.09.2019). 
58. ECHR in the case "Beian v. Romania" on December 6, 2007 (Application № 30658/05). URL: http://hudoc.echr.coe.int/eng?i=001-83822 (дата звернення: 26.09.2019).

59. ECHR in the case "Ferreira Santos Pardal v. Portugal" on July 30, 2015 (Application № 30123/10). URL: http://hudoc.echr.coe.int/eng?i= 001-156500 (дата звернення: 26.09.2019).

60. Шульга И.В. Понятие и виды правовых позиций Верховного суда Российской Федерации: автореф. дис. ... канд. юрид. наук: 12.00.01. М., 2016. 26 c.

Information about the author:

Bysaga Yu. M.,

Doctor of Law, Professor, Head of the Department of Constitutional and Comparative Law, Uzhhorod National University 26, Kapitulna str., Uzhgorod, 88000, Ukraine 